\title{
Preface
}

\section{You Are Who You Date?}

As we move through the world, our interactions with different individuals and groups help each of us learn who we are, what our identities mean to us personally, and how we are perceived by others. While this is true more broadly, I think this process can be magnified when it comes to romantic and sexual relationships. For instance, in my experience conducting interviews for this book, it was not uncommon to hear millennials frequently stress that their most noteworthy intimacy experiences have been transformative-have taught them valuable lessons about the world or about themselves. Though individual biographies around sexual and romantic intimacy are unique to each person, what we all share is the ability to use our experiences to gather information about who we are and what we want out of our lives and relationships. As I argue in the coming pages, experiences are important to millennials_or those who have birth years from the early 1980 s to the mid-1990s - since rather than rely solely on tradition, the current cultural conditions surrounding us in the West compel us to figure out for ourselves who we are and what we want out of life.

Though I am-like my participants-a millennial, this book is not about me. However, I wanted to use this preface as an exercise in reflexivity by showing how our individual lives connect to those of others, and how personal experiences connect to larger patterns beyond just ourselves. For instance, take Whitney's story. Whitney (a pseudonym) and I are both White, middle-class women who have had romantic and sexual experiences with men. Despite some evidence that millennials and other younger adults value gender equality, Whitney shares that she still grapples with negotiating gendered expectations that men her age may not face. As a twenty-eight-year-old woman who is not in a 
serious relationship, Whitney is starting to feel pressured by those around her to find a committed partnership and possibly get married: "[My sisters] have ideal relationships, really good guys. So of course, I'm getting the pressure of 'You're next! You're the last one!' ... It puts pressure on me... . I've just been hopping around so much, [maybe] it's just time to settle down somewhere." Even though she is feeling good about where she's at right now-in a new, longdistance relationship that allows her to have a boyfriend and still have her dayto-day freedom - the idea that it's time to "settle down" is starting to weigh on Whitney. As a woman in my thirties, I understand how Whitney feels about the anxieties related to aging and finding a partner. I also worry about getting older and balancing intimate life expectations while pursuing my own personal (nonromantic) interests. Although it seems there are more conversations happening now that disavow the idea that women must be married to get the most out of their lives, gendered expectations around the importance of pursuing committed intimate partnerships persist.

Though Whitney deals with stressful gender expectations, she also admits that she is relatively privileged when it comes to social class. Her good fortune became especially apparent in one of her previous relationships with a workingclass boyfriend. At the same time, Whitney shared that her experience caused her to wonder more about the significance of their class differences. In an example of what she meant by this, she shared, "Yeah, there were differences.... [For example,] I questioned why he'd be using food stamps when he was a student. Was it abusing the system, basically? I questioned that. And I never actually said this out loud, but the fact that he was doing student loans and whatnot, yet his father had an RV [recreational vehicle] and four snowmobiles in the garage-it was like, hmmm, something wasn't right!" In this quote, Whitney's experience with her ex-boyfriend reinforces a message about class differences. Her account marks her ex-boyfriend and his father as potentially dishonest people-an assessment that Whitney relates to their class position. The implication of Whitney's account is that it assigns value judgments to social class status and conveys the idea that compared to middle- and upper-middle-class people, working-class or poor people may be shady, suspicious, or not have their priorities straight.

Though I was initially taken aback a bit by Whitney's story, upon reflection I had to admit that I've participated in similar judgments myself. For instance, in my early twenties I shied away from the prospect of becoming romantically involved with men who had not gone to college or were not university students due to the misguided assumption that we would probably not have the same values and goals around pursuing higher education. Also during that time, I received advice from a friend that pursuing a romantic interest who was wealthy might be a bad idea, lest I be rejected for not coming from the right class background. 
Though Whitney and I have different biographies, both of our stories reflect the shared idea that maybe it's best to stick to romantic partners with a class position similar to your own. This message is not neutral-it reinforces the understanding that the "type" of person you are is supposedly related to your social class and can also predict compatibility.

Though Whitney's story is different from mine, there are similar ideas about identity, power, and status in society influencing both of our stories. While we may indeed be distinctive in the intricacies of our stories, it is nevertheless apparent that there are things we share. The messages about class and gender that we have garnered through our experiences are seemingly much the same: class operates in a clearly hierarchical manner, and normative expectations for women still very much involve intimate partnership with men by a certain age.

Yet, while it is interesting and perhaps comforting to explore our similarities, it is equally as important, if not more so, to consider differences. Race and sexual identity do not figure prominently in Whitney's story, which is likely due to her identity as a straight White woman. However, as I discuss in the coming pages, the option of not having to think too much about sexual identity or race is usually not available to those who do not identify as White and/or as straight. Since the millennials interviewed for this book use their stories to make sense of their individual selves, their places in society, and even their partners, what is said and mulled over is as significant as what goes unsaid or unnoticed. Further, while Whitney and I have vivid understandings of where we have struggled, it may be less obvious to us how our actions may affect others. Unbeknownst to her, Whitney's ex-boyfriend may have perceived her disdain toward his use of food stamps, and it may have had some impact on his understanding of himself or his understandings of what it is like to date women like Whitney. It is easy to recognize one's own struggles and dilemmas, but it is sometimes more difficult to see when we might devalue, misinterpret, or even exacerbate the struggles of someone else.

The stories I share throughout this book are from millennials who are like me and are from millennials who are not like me. Their stories reveal shared experiences, and different experiences, among a group of young adults concentrated in the western United States. Throughout the rest of the book, my own narrative is absent in order to center the stories of the millennials I interviewed. It is my hope that through examining their stories we can begin to see how identity- and status-based inequalities are often perpetuated, and sometimes challenged, through routine intimate relationship experiences. It is also my hope that in examining these millennials' stories we may better understand how to address lingering identity- and status-based inequalities in our private, and also our public, lives. This book is about millennials and how they use their relationship stories to make sense of themselves, their partners, and 
how they subsequently navigate social and identity differences-based on race, social class, gender, sexuality, and age - in their intimate lives. However, I argue that what millennials do in intimacy is bigger than them. The traditions of the past, as much as the expectations of the present, help inform how millennials make sense of and navigate their intimate lives. Millennials' stories reveal how the landscape of intimacy is changing... or in some cases, how it is not. 


\section{Intimate Inequalities}


